\title{
Orchestrating Transnational Environmental Governance in Maritime Shipping
}

\author{
Lister, Jane ; Taudal Poulsen, René; Ponte, Stefano
}

\author{
Document Version \\ Accepted author manuscript \\ Published in: \\ Global Environmental Change
}

DOI:

10.1016/j.gloenvcha.2015.06.011

Publication date:

2015

Citation for published version (APA):

Lister, J., Taudal Poulsen, R., \& Ponte, S. (2015). Orchestrating Transnational Environmental Governance in Maritime Shipping. Global Environmental Change, 34(September), 185-195.

https://doi.org/10.1016/j.gloenvcha.2015.06.011

Link to publication in CBS Research Portal

\section{General rights}

Copyright and moral rights for the publications made accessible in the public portal are retained by the authors and/or other copyright owners and it is a condition of accessing publications that users recognise and abide by the legal requirements associated with these rights.

\section{Take down policy}

If you believe that this document breaches copyright please contact us (research.lib@cbs.dk) providing details, and we will remove access to the work immediately and investigate your claim. 


\section{Orchestrating transnational environmental governance in maritime shipping}

René Taudal Poulsen, Jane Lister, and Stefano Ponte

Journal article (Post print version)

This article was originally published in Global Environmental Change, Volume 34, September 2015, Pages 185-195.

DOI: $10.1016 /$ j.gloenvcha.2015.06.011

Uploaded to Research@CBS: September 2015.

Available at: http://research.cbs.dk/da/publications/orchestrating-transnationalenvironmental-governance-in-maritime-shipping\%280d1a45e2-7d61-4676-a42fca4407257327\%29.html

(C) 2015 Elsevier 


\section{Orchestrating transnational environmental governance in maritime shipping}

\section{Introduction}

Maritime shipping is the transmission belt of global production, trade and consumption and carries ninety percent of international trade volume (measured in tonnes) (Hoffman and Kumar 2010; UNCTAD 2014). Compared to other transport modes, sea transport has had a relatively 'green image' because ships generally emit less $\mathrm{CO} 2$ per ton-mile than rail, truck or air transport. Yet, given its scale and rapid growth, the maritime sector is a major contributor to global ecological change (Smith et al. 2014; Buhaug et al. 2009; Dalsøren et al. 2009). The environmental footprint of shipping relates to a diversity of issues ranging from oil spills and air emissions to invasive species, disposal of hazardous material and noise. Despite its measurable ecological impact, the sector remains largely unaccountable, with the transnational environmental governance (TEG) of shipping seriously lagging. This is puzzling considering that maritime shipping has its own dedicated international organization (the International Maritime Organization - IMO) that could be expected to catalyze efforts for environmental improvements (Karim 2015).

Drawing on original empirical evidence and engaging with theories of transnational governance, we employ a four-factor framework to explore two main questions: why is the shipping industry lagging behind other sectors in terms of environmental governance; and what is the potential for the International Maritime Organization to orchestrate private, hybrid and public initiatives to achieve better environmental outcomes? Recent literature on transnational governance argues that governments and international organizations need to better orchestrate (i.e. engage and facilitate) a wider variety of actors and factors if they want to achieve their objectives (see, among others, Abbott and Snidal 2009a; 2009b; 2010; 2013; Schleifer 2013; Hale and Roger 
2014; Abbott et al. 2015; Graham and Thompson 2015). Examining specifically, the focal role of the International Maritime Organization as a lead international regulator, we take orchestration to entail public organizations using a combination of direct and indirect tools, and hard and soft power, to address global environmental problems. This includes more traditional regulation (and regulatory threat) and international agreement formation, but also working with industry actors and civil society groups in collaborative ways, delegating environmental authority to these nonstate actors (Green 2014), and actively using intermediaries (Abbott et al. 2015). The analytical framework we employ is centered on four dimensions affecting orchestration: issue visibility, interest alignment, issue scope, and regulatory fragmentation and uncertainty. Through the framework we reveal and assess the challenges and opportunities for environmental progress.

The article unfolds in several parts. In section 2, we review the relevant literatures on transnational environmental governance in shipping (and other sectors more generally), in order to delineate the analytical framework and provide the context for orchestration as a conceptual key. Section 3 explains our methodology and data collection procedures. Section 4 evaluates how environmental regulation in maritime shipping has evolved (and lagged) relative to onshore industries, and the significance of shifting business attitudes in shaping the regulatory landscape. Section 5 analyzes how private 'green shipping' initiatives are emerging and their potential policy role in influencing and establishing transnational environmental standards. In section 6, we return to our analytical framework to explain why environmental governance in shipping is underperforming. And finally, we conclude with the implications of our analysis for the future role of the International Maritime Organization in orchestrating more effective progress to mitigate the global environmental impacts of maritime shipping. 


\section{Literature review and analytical framework}

Given the major importance of shipping in the global economy (UNCTAD 2014) and mounting pressures on the world's oceans (Merrie et al. 2014), the relative lack of research on shipping governance, and especially on the global regulation of its environmental impacts, is surprising. Within the legal field, analyses have focused mainly on territorial jurisprudence such as concerning the Law of the Sea and currently with respect to arctic shipping and offshore drilling (Molenaar 2009; Young 2009). Tracing the political literature over several decades yields only a few significant accounts: Gold's (1981) history of maritime policy, Cafruny's (1987) analysis of the rise and fall of consecutive shipping regimes, and Strange (1976), McGonigle and Zacher (1979) and Zacher and Sutton's (1996) explorations of the economic and political dimensions of the international shipping regime - including the underlying norm of 'freedom of the seas' and the 'hidden agenda' of social and environmental concerns. Mitchell (1994) analyzed international treaty effectiveness in the case of intentional oil pollution at sea, and Cutler (1999) subsequently investigated the evolving nature and implications of the hybrid public-private nature of the regime, highlighting how international shipping represents the oldest and most established example of private authority in global governance. Beyond these early analyses, the sector has been virtually ignored in the transnational governance literature, including within the growing body of research on global environmental regimes.

Research on transnational environmental governance (TEG) in shipping notably lags well behind research in other sectors (such as forestry, fisheries, agriculture and manufacturing). While technical analyses of green shipping are emerging, questions about effective governance are generally not addressed. Environmental topics covered include: ship recycling, energy efficiency, ballast water management, and emissions of $\mathrm{CO} 2$, particulate matter, Sulphur Oxides (SOx) and 
Nitrogen Oxides (NOx) (For specific examples see: Bax et al. 2003; Corbett et al. 2007; Asariotis and Benamara 2012; Briski et al. 2012; Hiremath et al. 2015). Of the few international environmental governance studies conducted on the shipping sector: DeSombre (2006) examines the implications of the open ship register system on marine environmental protection, safety and labor conditions arguing that shipping standards have gravitated towards the 'regulatory middle', despite the rapid growth of open registers; Tan (2006) evaluates the regulation of vessel-source pollution in different socio-economic contexts; Roe (2013) argues why a state-centric, hierarchical governance framework has failed to effectively regulate environmental and social issues; and Hackmann (2012) highlights the concern of growing regulatory fragmentation within shipping environmental governance in the case of climate change. With the exception of Van Leeuwen (2010) and Karim's (2015) overviews of the role of the International Maritime Organization, there has been no attempt so far at examining the actual or possible functioning of the International Maritime Organization as a TEG orchestrator.

We see TEG as operating 'in a political sphere in which public and private actors interact across borders and political jurisdictions' (Andonova et al. 2009: 69) to address environmental concerns. TEG is a fragmented and multi-layered field where inter-governmental organizations and treaties operate alongside, and in interaction with, market-based instruments and different kinds of partnerships (Haas 2004; Bäckstrand 2008; Andonova et al. 2009; Andonova 2010). As the literature describes, TEG occurs where a range of mutually-dependent interacting private and public actors share governance authority within overlapping governance arenas giving rise to hybrid regulatory features and cross-border rule-making, implementation and enforcement activities (Biermann 2007; Mol 2010). The governance complexity involved in TEG can promote self-interested behaviors of individual actors pursuing their own goals such as through forum 
shopping (Alter and Meunier 2009; Fransen 2012; Schleifer 2013). However, as we present in the case of green shipping private initiatives, it can also establish experimental and more flexible venues to solve environmental problems, especially in the absence of an effective international regime (Sabel and Zeitlin 2008; Abbot and Snidal 2009; Keohane and Victor 2011). For some, these hybrid forms of governance are able to by-pass stalled international agreement processes, and can provide moral pressure eventually leading to the improvement of environmental standards (Overdevest and Zeitlin 2014). We see this trend of experimental private governance innovation in the face of stalled international agreements emerging in the shipping regime. As we argue, while private governance mechanisms and arenas are forming, the role of the International Maritime Organization as orchestrator is so far, under-developed.

As the literature shows, the development, adoption, and enforcement of TEG depends on strong state capacity and committed inter-governmental action (Gale and Haward 2011; Lister 2011; Foley 2012; Guldbrandsen 2014; Auld 2014). In particular, national and international governmental engagement is aided where public and private norms, objectives, and interests align (Verbruggen, 2013). One main strand of the TEG literature is focused on understanding the numerous transnational experiments and entrepreneurial governance initiatives that are being carried out by industry associations and individual corporations, international and local NGOs, and other non-state actors (Dingwerth and Pattberg 2009; Andonova et al. 2009; Hoffmann 2011; Green 2013; 2014). Another strand is concerned with the possible mechanisms and strategies that nation states and international organizations can use to shape environmental outcomes (Keohane and Victor 2011; Hale and Roger 2014; Abbott et al. 2015). A major source of concern in this latter strand remains the 'fragmentation' of governance architectures in the environmental field (Biermann et al. 2009; Zelli and van Asselt 2013) and the resultant 'governance deficit' (Haas 
2004). As sections 4 and 5 reveal, regulatory fragmentation in maritime shipping governance is growing with respect to the multi-level divergence of international, regional, national, local (port authority) and private standards. As TEG theory projects, the problem of a governance gap in shipping is consequently increasing in terms of regulatory rule-making uncertainty, delayed implementation and weak enforcement.

The concept of orchestration has provided a useful analytical and normative tool to address this transnational governance deficit. Abbott and Snidal (2009b) refer to a wide set of mechanisms under the concept of orchestration, some of which are defined 'directive' and others 'facilitative' (see also Schleifer 2013). Directive orchestration is seen as relying on the authority of the state and seeking to incorporate private initiatives into its regulatory framework, for example through mandating principles, transparency, and codes of conduct (Abbott and Snidal 2009b). Facilitative orchestration relies on softer instruments, such as the provision of material and ideational support, such as financial support, technical support, endorsement (Ibid.) in order to kick-start new initiatives and/or to further shape and support them (Hale and Roger 2014). Hale and Roger (2014: 60-61) refer to this view of orchestration as 'a process whereby states or intergovernmental organizations initiate, guide, broaden, and strengthen transnational governance by non-state and/or sub-state actors'. In more recent work, however, Abbott et al. (2015: 4) use a narrower definition of orchestration to be applied to situations when a governor 'enlists and supports intermediary actors to address target actors in pursuit of intergovernmental organization (IGO) governance goals'. Orchestration from this perspective (Ibid.: 9) is a specific form of governance through intermediation, characterized by soft instruments and indirect influence on target actors, which distinguishes it from three other kinds of governance: hierarchy (hard instruments, direct 
influence), collaboration (soft, direct) (Andonova 2010; Hoffmann 2011), and delegation (hard, indirect) (Green 2014).

In our article, we use a broader conceptualization of orchestration as 'a strategy through which states or international organizations bring new capacities and resources to the provision of global public goods by strengthening or catalyzing transnational governance schemes' (Hale and Roger 2014: 63). We do this in recognition that public governors use different combinations of governance mechanisms to attempt to achieve policy goals, in the context of industry and/or issue specificity. In other words, orchestrators may combine straight regulation (or the threat of future/stronger regulation) with collaboration, delegation, intermediation and other hybrid mechanisms, such as placing their own representatives in key positions in intermediary organizations (Author 2015).

Our analytical framework to assess the likelihood of successful public orchestration is based on four dimensions: regulatory fragmentation and uncertainty; issue visibility; interest alignment; and issue scope. On regulatory fragmentation and uncertainty, we can expect more difficult conditions for orchestration in situations when public regulation of environmental concerns is fragmented and uncertain, and when relevant private or hybrid initiatives are multiple and diverse (Haas 2004; Beiermann et al 2009; Zelli and van Asselt 2013; Alter and Meunier 2009; Fransen 2012). On issue visibility, we can expect more potential for orchestration if the industry involved, and the related set of environmental issues, are clearly visible to the general public and to consumers (Dauvergne and Lister 2012). On interest alignment, we can expect better orchestration possibilities if there is substantial overlap between public and private interests, and relative cohesion internally within each sphere (Verbruggen 2013; Schleifer 2013). Finally, on 
issue scope, we can expect orchestration to be more likely to succeed when addressing a narrower, more specialized set of issues, rather than a more comprehensive set (Auld, 2014).

\section{Methodology}

In order to analyze the factors shaping the environmental protection standards of global shipping, we apply a mixed method approach. A very broad selection of interviews and diversity of written sources allowed us to thoroughly assess different stakeholders' views and to examine how environmental protection standards are determined and evolve. We performed semi-structured, indepth, confidential interviews with 37 executives and middle managers in container, tanker and dry bulk shipping companies over a two-year period (2012-2014). The interviews centered on three aspects: (a) the role of environmental regulation in shipping; (b) the role of green rating schemes in shipping; and (c) the competitive implications of environmental governance (see Supplement 1 for the interview guide). In total we interviewed 20 Danish, one German and two Canadian shipping companies (see Table 1). These companies are not representative of the global ship-owner community in a statistical sense: on average Danish ships are younger than the world fleet, and Danish ship-owners usually prefer to market themselves as 'quality shipping' (Danish Shipowners' Association 2015). To partly control for national bias in interviews, and to follow changes over time, we triangulated our interview data with a comprehensive desktop review of environmental protection positions held by the main national and international ship-owner associations since 1990 (see Supplement 2), as found in position papers and annual reports (see, e.g. ECSA 2009; ICS 2015; BIMCO 2015; Norwegian Shipowners' Assocation 2014; UK Chamber of Shipping 2012). Finally, we identified agendas and prevailing attitudes on 
environmental regulation as reported in Lloyd's List (the leading, global shipping newspaper) through an archival search on the keywords SOx, NOx, $\mathrm{CO} 2$ and ballast water.

To analyze the decision-making process at the International Maritime Organization, we searched the electronic archive IMODOCS for documents concerning $\mathrm{CO} 2$, SOx, NOx or ballast water. IMODOCS contains the meeting agendas of the Marine Environmental Protection Committee (MEPC), participant lists, submissions from national governments, international shipowner associations, NGOs and other members. To analyze the role of private greening initiatives in possibly shaping environmental protection standards, we relied on interviews with key stakeholders. In addition to our interviews with ship-owners, we interviewed individuals in four major Nordic cargo-owner companies that ship up to 170,000 TEUs (twenty-foot equivalent container units) annually (three manufacturers of branded consumer goods, as well as one retailer). We also interviewed three middle managers in classification societies as they represent a wellestablished centuries-old self-governance mechanism in shipping, and two representatives of NGOs that promote new transnational green rating schemes in shipping.

\section{The evolution of international environmental regulation in shipping}

Environmental protection standards to control for maritime shipping pollution and biodiversity damage have evolved slowly since 1990. With the exception of oil spills, regulatory development has been stalled with respect to all of the major issue areas including $\mathrm{CO} 2$ and other emissions, and invasive species. In this section, we demonstrate first, how shipping lags on these issues relative to onshore industries and second, how ship-owner perspectives on environmental regulation, in particular have limited the development of international regulation. 
Created in 1948, The United Nations' International Maritime Organization (IMO) is a focal inter-governmental regulatory body and as such, could be expected to orchestrate the transitional environmental governance of shipping. The International Maritime Organization has a mandate to promote maritime safety, security and environmental protection to 'create a regulatory framework for the shipping industry that is fair and effective, universally adopted and universally implemented' (IMO 2014b). As such, it has authority over several important international conventions such as the International Convention for the Prevention of Pollution from Ships (MARPOL), the Convention for Safety of Life at Sea (SOLAS), and the International Convention on Standards of Training, Certification and Watchkeeping for Seafarers (STCW). MARPOL is the main convention concerned with environmental protection and since its adoption in 1973 has been amended with several annexes added. International Maritime Organization conventions and amendments enter into force when contracting governments (flag states) enact them in national legislation. However, in many cases, conventions have been delayed and in some instances never entered into force due to insufficient ratification among member states. For some conventions ratification processes can last a decade or longer (IMO 2015a). Tracing the development of environmental regulation in shipping, the International Maritime Organization's policy agenda has broadened significantly over time from oil spills and garbage handling to $\mathrm{CO} 2$ emissions, $\mathrm{SOx}$, NOx and particulate, to controlling ballast water discharge and the mitigation of marine ecosystem damage from invasive species.

Oil spills

With the advent of super tankers in the 1960s and 1970s, environmental regulation discussions at the International Maritime Organization were largely focused on oil spill prevention (Mitchell 1994). Issues related to sewage and garbage handling from shipping and hazardous materials in 
hull paints were also discussed, but a series of major oil spills from tankers in the 1960s and 1970s caught the public's and the International Maritime Organization's main attention. Public outcry following the 'Exxon Valdez' oil spill in Alaska in 1989 (as conveyed by our tanker shipping interviewees) was a turning point in oil spill prevention and International Maritime Organization regulation including the resulting 1992 'double hull' amendments to the MARPOL convention. Since 1989, cargo-owners (oil majors) have demanded higher tanker safety standards - leading to a significant reduction in oil spills (Huijer, 2005; Burgherr, 2007; Mukherjee and Brownrigg, 2013; Authors 2015).

\section{CO2 emissions}

Since the 1990s, new environmental concerns have surfaced, and global climate change mitigation has also become a key issue in shipping circles. During the period 2007-12, shipping accounted for an average of 2.8 percent of annual, global CO2e emissions (Smith et al. 2014: 14). Due to the highly mobile and transnational nature of the sector, allocation of maritime emissions to a specific nation has proven difficult, and the sector was left out of the Kyoto Protocol in 1997 (Oberthür and Ott, 1999). The issue of emissions was passed on to the International Maritime Organization, which has since discussed various market-based measures (MBMs) (an emission trading scheme or a bunker levy) to cut emissions, but without reaching any comprehensive agreement (Buhaug et al. 2009; Asariotis et al. 2012; Psaraftis 2012; IMO 2015b).

The first regulation adopted by the International Maritime Organization to mitigate global climate change entered into force in 2013 and consists of two technical measures: 1) the Energy Efficiency Design Index (EEDI), which is a minimum design requirement for energy efficiency for all new ships; and 2) the Ship Energy Efficiency Management Plan (SEEMP), a mandatory document for existing and new ships, specifying operational initiatives to enhance energy 
efficiency. The SEEMP requirements are vaguely specified (Johnson et al. 2013) and in the coming decades the EEDI and SEEMP are expected to only slow down growth in emissions, which are actually expected to rise in absolute terms due to a forecasted global growth in demand for shipping (Bazari and Longva, 2011; Smith et al. 2014). To achieve absolute emission reductions, far more radical initiatives are required (Bows-Larkin et al. 2015, Anderson and Bows 2012).

In response to weak International Maritime Organization leadership, regions are now acting unilaterally. The European Commission has voiced dissatisfaction and has stepped in, first with the threat of regional regulation and then with its actual application. The EC is now pursuing a mandatory scheme for monitoring, reporting and verification of $\mathrm{CO} 2$ emissions (MRV) for ships calling at European ports (Lloyd's List 2011a; 2011b; European Commission 2013; European Commission, 2015a). The MRV scheme will enter into force in 2018 and thus add a new, regional layer to the maritime regulation on CO2 emissions (European Commission 2015a). Discussions on a global MRV scheme are, however, now finally under discussion in the International Maritime Organization, while the controversial issue of MBMs remains unresolved (Lloyd's List 2015a).

\section{Other emissions}

Other major environmental issues now entering into the global policy arena relate to emissions of SOx and NOx, which cause acidification, eutrophication, as well as human health problems and premature deaths (Dalsøren et al. 2009; Smith et al. 2014; Corbett et al., 2007; van Aardenne et al., 2013). The vast part of the world fleet burns Heavy Fuel Oil (HFO), a residual product from crude oil refining. HFO is literally 'the bottom of the oil barrel', and has considerably higher sulphur content than fuels used for example, by trucks (Corbett et al. 1997; Nikopolou et al. 2013; Smith et al. 2014, p. 273; Dieselnet 2015). In the period 2007-12, shipping accounted for 15 and 13 per cent 
of all global, anthropogenic NOx and SOx emissions respectively, with absolute levels of emissions remaining stable (Smith et al. 2014: 139). But because onshore industries (such as power generation) have reduced NOx and SOx emissions, the relative weight of shipping emissions has increased (Viana et al. 2014). By 2020, forecasts for the EU area suggest that NOx and SOx emission levels from shipping will approximately equal all other emission sources combined (Nikopolu et al. 2013; Viana et al. 2014). Likewise, the International Maritime Organization forecasts considerable growth in global NOx emissions in the coming decades (Smith et al. 2014: 36).

Discussions on how to best address these emissions started far earlier in onshore industries than in shipping (Schmalensee et al. 1998), where they entered the agenda only in 1997 when the International Maritime Organization amended the MARPOL convention to set the first limits to air pollutants (IMO 2015). Recently, however, some regulatory changes have been taking place: MARPOL Annex VI has been tightened, and the International Maritime Organization has designated the Baltic and North Seas and North American coastal waters as Sulphur Emission Control Areas (SECAs), requiring a reduction in the cap for sulphur content in marine fuel from 1 to 0.1 percent from January 1,2015 . In order to comply with the 2015 SECA regulation, shipping companies can choose to: clean exhaust gas (by installing scrubbers, a new technology in shipping, but a well-known one used in onshore power plants); shift from HFO to Marine Gas Oil (MGO) with 0.1 per cent sulphur content; or shift to other cleaner types of fuel, such as liquefied natural gas (LNG) or methanol. The regulation faces barriers. All compliance measures add considerable costs to ship operations, and in the case of LNG very little fuelling infrastructure is currently available (Cullinane et al. 2014). A global reduction in the cap for sulphur content in fuel (i.e. in non-ECA areas) from the current 3.5 percent to 0.5 percent is planned by the International 
Maritime Organization for 2020. This is subject to the outcome of a fuel availability study in 2018, with possible deferral to 2025 (IMO 2015a). However, even the strictest fuel-sulphur content limits in SECAs are weaker than those applying to trucks in Europe by a factor of 100 (Dieselnet 2015; European Commission 2015a, 2015b). And as indicated by the Third IMO GHG study from 2014 (p. 115), "sulphur content in marine fuel, used by vessels operating outside SECA areas, still averages $2.5 \%$." This is 2,500 times higher than automotive diesel fuels.

In 1997, the International Maritime Organization also started to address NOx-emissions, with the new Annex IV in MARPOL. Even though regulation has been gradually tightened since then, the first major change (referred to as Tier III) is only scheduled to take place in 2016 in specially designated Emission Control Areas (NECAs) in North American coastal waters (IMO 2015a). A Tier III NECA designation of the North and Baltic Seas was expected to take place in 2016, but it has not materialized due to opposition in the International Maritime Organization, mainly from Russia (Danish Shipowners Association 2012, Lloyd's List 2014a). Shipping is also a considerable and increasing source of other types of air emissions, including 'black carbon' and particulate matter (PM), for which emission levels are expected to rise in the coming decades (Smith et al. 2014: 36; Viana et al. 2014. These emissions have negative human health impacts and are potent climate forcers. PM emissions also occur in trucking, but effective filters have been installed in vehicles in many developed countries to address this. PM emissions remain particularly challenging for the shipping industry due to the industry's reliance on Heavy Fuel Oil. As indicated by a report commissioned by IMO (Litehauz et al. 2012: 6), "ships emit more particulate matter (PM) and BC per unit of fuel consumed than other fossil fuel combustion sources due to the quality of fuel used." 
In sum, for other emissions the International Maritime Organization is taking a regional regulatory approach in some ways similar to what the EU is doing with the MRV scheme for $\mathrm{CO} 2$ emissions, in the hope of being able to globalize such schemes in the mid-term.

\section{Invasive species}

An issue that has arguably lagged the most concerns invasive species. The damage from the spread of non-native species to ecosystems and biodiversity, both onshore and in aquatic environments is well documented. Invasive species are transported in ballast water, which ships carry to ensure stability (Bax et al. 2003; Molnar et al. 2008; DiBacco et al. 2012; Briski et al. 2012; Chan et al. 2013). This issue has been high on the onshore political agenda in forestry, agriculture, and other sectors for decades (Sala et al. 2000; Mehta 2007) and has led to the conclusion of important conventions, such as the International Plant Protection Convention (IPCC). Yet, this issue only entered the agenda of the International Maritime Organization following the 1992 UN Conference on Environment and Development in Rio (IMO 2015a), leading to the Ballast Water Management Convention (BWMC) in 2004. This requires ballast water treatment on all ocean-going ships and is expected to enter into force 12 months after ratification by 30 percent of all member states, representing at least 35 percent of global tonnage (IMO 2014). However, the ratification process has now been going on for over a decade, and while the convention is expected to eventually enter into force, the US has declined to participate. Instead, and similar to what the EU has done on CO2 emissions, the US is acting unilaterally by placing special (and more rigorous) approval requirements for ballast water management system on ships calling at US ports (USCG 2014).

Furthermore, while the IMO Ballast Water Convention addresses the spread of invasive species via ballast water (but not yet in force), the major source of invasive species from the outside hull of ships has not received much attention. It was only discussed in IMO for the first 
time in 2006 and a guideline was developed and adopted in MEPC in 2011 (MEPC 207/62). As yet, no IMO convention addresses the issue of common hull biofouling.

\section{Other Issues}

And finally, significant environmental issues also relate to ship recycling (scrapping) which requires handling of hazardous materials (such as asbestos and ozone-depleting substances) (Hiremath et al. 2015). The IMO initiated discussions on ship recycling in the year 2000, and in 2009 it agreed on the Hong Kong International Convention for the Safe and Environmentally Sound Recycling of Ships to address this issue. To quote the IMO (2015c): “The Hong Kong Convention intends to address all the issues around ship recycling, including the fact that ships sold for scrapping may contain environmentally hazardous substances such as asbestos, heavy metals, hydrocarbons, ozone-depleting substances and others." However, the convention has not yet been sufficiently ratified to enter into force. Only three parties (representing 1.86 percent of world tonnage) had ratified the convention as of June 14, 2015 (IMO 2015a).

\section{Shipping industry perspectives on regulation}

Industry perspectives on environmental regulation have contributed to shaping the dynamics of inter-governmental regulation, or lack thereof, in the shipping sector. Across flags and segments, ship-owners have expressed different positions, but a common concern has been maintaining the 'green image' of the industry. As stated by BIMCO, the world's largest international shipping association with 2,300 members in around 130 countries: '...that trans-oceanic shipping is the

most environmentally friendly and cost-effective mode of transportation is uncontested' (BIMCO 2015).

While national and international ship-owner associations all adopt the rhetoric of concern for the environment, they largely remain critical of new regulation. They argue it adds costs and undesirable complexity to ship operations, distorts competition within the industry itself 
and reduces the competitiveness of shipping vis-à-vis other transport modes (BIMCO 2015; ICS 2015). BIMCO emphasizes that new regulation needs to be workable in practice, and that ratification and implementation of existing International Maritime Organization regulation should take precedence over the development of new ones (BIMCO 2015). Moreover, our analysis of Lloyd's List clearly shows that ship-owners have lobbied actively against SECAs, NECAs, the BWMC and MBMs for CO2 emissions (See for example: Lloyd's List 2010; 2011b; 2011c; 2012; 2014a; 2015a; 2015b).

While generally against new laws, ship-owners unanimously prefer global regulation and the International Maritime Organization is the preferred regulator (BIMCO 2014b; ICS 2015). They argue that regional regulation is incompatible with the transnational nature of ship operations, adds costs and undesirable complexity to ship operations, and hampers international trade. Lobbyists for the industry have been successful in avoiding the inclusion of shipping in the UNFCCC negotiations so far, fearing that shipping may become a 'cash cow' for climate change mitigation onshore (Lloyd's List 2012; ICS 2015). However, ship-owners have not been successful in preventing regional regulation on ballast water and MRV, as shown above.

From the perspective of ship-owners, rather than providing compliance options, an increasingly fragmented regulatory system adds new challenges and uncertainties to their business operation. But regulatory uncertainty is also problematic for their investment decisions. Given the typical 25-year commercial lifespan of ships, ship-owners need to take these regulatory uncertainties into account when selecting designs and equipment for new ships. An investment in an LNG-fuelled ship today, for instance, will become more attractive if the new global sulphur cap enters into force in 2020, rather than in 2025. The dynamics around regulatory timing shape industry perspectives and response. The uncertain timing of the new cap makes ship-owners more 
wary of investing in environmental improvements and it slows down the efforts to raise environmental protection standards. At the same time, ship-owners are co-responsible for this uncertainty as they fight against regulatory changes.

Our analysis also reveals a recent and increasing divergence within the industry. A change in mindset is emerging in parts of the ship-owner community towards more proactive action. While largely remaining critical about market-based measures (MBMs) (BIMCO 2014a; ICS 2015), some national associations now support MBMs to reduce CO2 emissions (see, e.g., Danish Shipowners' Association 2012, Norwegian Shipowners' Association 2014) and the EU MRV proposal (Danish Shipowners’ Association 2014). Divergence among ship-owners is also discernable in relation to SECAs. For several years, the shipping industry lobbied strongly against the SECA in the North and Baltic Sea (ECSA 2009: 19). But in 2014, as the SECA deadline approached, the Trident Alliance was created - a rapidly growing coalition of mainly Scandinavian shipping companies that seeks to promote strong SECA enforcement. They fear weak enforcement may incentive some companies not to comply to achieve competitive advantages. Many of our Danish shipping company interviewees also complained about the impact of uncertainties in the timing of regulatory implementation and criticized the incoherence and piecemeal nature of International Maritime Organization regulation. For instance, many pointed to the fact that ballast water treatment and exhaust gas cleaning will increase energy consumption and lead to higher $\mathrm{CO} 2$ emissions - a perspective also shared by e.g. the UK Chamber of Shipping (UK Chamber of Shipping 2012: 11).

Finally, other environmental issues related to other types of emissions, underwater noise from propellers and engines, and hull bio-fouling are also under regulatory consideration in the 
International Maritime Organization, but remain largely unresolved. Ship owners view this as adding further complexity and uncertainty to their operations and investment decisions.

Not surprisingly, the industry has pushed back over the past several decades on new regulation. However, now there is a shift with some major shipping companies forming alliances to encourage regulation, with expectations on the International Maritime Organization to step up its role to ensure consistency in global rules and strong enforcement for a level playing field. As we explore and assess in the next section, the slow progress in environmental shipping regulation at the international level has opened up a space that is being filled by a number of private and hybrid forms of governance (Author 2015). This in turn we argue, is creating an opportunity for the International Maritime Organization to respond to growing corporate expectations to strengthen its role and influence by potentially leveraging and orchestrating these emerging new private regulatory initiatives for greater progress.

\section{Voluntary 'green shipping' standards and rating schemes}

The lack of coherent international environmental regulation in shipping is spurring new private voluntary governance mechanisms (Lister 2015). In the absence of International Maritime Organization orchestration of these initiatives, increased disjuncture in the architecture of the transnational governance regime is occurring. This is particularly the case as the EU and the US act to regulate and orchestrate on their own within their respective domains. As this section evaluates, the rise of many different transnational green shipping standards is creating new governance challenges for the International Maritime Organization within an increasingly hybridized global regulatory landscape. 
While shipping has a long tradition of voluntary self-regulation in the realms of freight market contracts, marine insurance and ship safety (Cutler 1999; Paulsen et al. 2014), private and hybrid initiatives have started to influence environmental protection standards only since the early 2000s. With the knowledge of growing regulatory pressures but uncertain implementation features, companies along the maritime value chain are increasingly participating in multistakeholder initiatives on 'green shipping' and in the development and adoption of industry-led voluntary standards. These are serving to provide environmental goalposts, tools for measuring and accountability, comparative benchmarks, as well as deliberative arenas for industry to debate and chart a possible new course. They are also presenting a range of challenges for shipping operators.

A major driver of shipping company participation in the widening array of voluntary green shipping programs include increasing demands from their customers. Cargo-owners, particularly the large global brand companies in the container sector, are beginning to pressure their carriers to either report or act on selected environmental issues (Authors 2015). Expectations are building for the provision of more detailed environmental data from shipping companies, with some cargo owners planning to introduce environmental audits of their carriers. This movement, however, is still at its early stages. As shipowners noted, most cargo owners do not yet follow up on the information provided, nor do they use these data; only a select few have (partly) integrated sustainability considerations into their procurement decisions. Price and reliability continue to be the essential contractual considerations. The container sector is much more active on these issues than bulk or tanker shipping, where oil spill prevention largely remains the only environmental concern (Authors 2015). 
Private demands from cargo-owners also involve participation in new 'greening' initiatives, such as the Clean Cargo Working Group (CCWG) and the NGO-led Sustainable Shipping Initiative (SSI). Although these are still small in scale, cargo owners and shipping companies are paying increasing attention to them. Out of interest for a uniform means to calculate and report on carbon emissions, cargo owners are encouraging their shipping carriers to join the CCWG and adopt its standardized carbon measurement tool. 'Last year we required them to report to the CCWG and this year they will need to be members,' a cargo owner explained (2014 interview). When asked why a carrier would voluntarily join CCWG, it was stressed that 'there are a lot of countries that need to agree on an international carbon standard. It is more optimistic to get cargo owners to agree.'

The CCWG and SSI are complementary initiatives. The CCWG was formed in 2003 by the industry-led NGO, Business for Social Responsibility (BSR). The group includes cargo-owners and shipping companies as members and aims at improving the transparency and environmental performance of container ships and shipping companies through standardized measures and what they identify as 'best practices'. The SSI sees itself more as a 'lighthouse', providing a vision and future direction for sustainable shipping efforts. SSI was established by the Forum for the Future and includes the participation of the WWF as well as cargo-owners (e.g. Unilever) and shipping companies. While the CCWG is setting private standards, the SSI aims to also influence policymakers - to inspire the International Maritime Organization and other regulators to advance greener shipping practices. The SSI has developed an online tool and published a report to help sort through the many green shipping rating schemes that have emerged in recent years (see Table 1), as the inconsistencies are deemed to be jeopardizing progress (SSI 2014). SSI does not reveal how frequent each program is used, but our interview data reveal the CCWG, the Clean Shipping 
Index, Right Ship, and the prospect of port incentives for green ships (such as with the Green Award scheme) to be the most frequently cited.

\section{$\langle$ TABLE 1>}

These schemes are only starting to influence environmental protection standards in shipping: out of a world fleet counting more than 47,000 commercial vessels (of 1,000 GT and above), they only cover a small share (e.g. CSI currently lists 2,000 vessels and CCWG 2,300 vessels; SSI 2014). Although addressing the same overall objective to reduce the environmental impact of shipping, they target widely different audiences with different aims and needs. Some schemes allow shipping companies and cargo-owners to benchmark individual vessels, while others are used as inputs for green incentive schemes devised by some port authorities (see below). Different schemes target different segments of the shipping industry: e.g. CCWG is focused on container shipping only; Right Ship on tankers; and the Clean Shipping Index (CSI) on container vessels, bulk carriers, cruise and roll-on/roll-off ships. As our interview data reveal, the diversity of schemes offers important market choice but also creates confusion. The scope of environmental problems addressed in the rating schemes also differ (see Table 1), as do definitions and data reporting methodologies. Some schemes use absolute data (e.g. CCGW calculates gram $\mathrm{CO} 2$ per TEU-km and gram NOx per kWh), while some rely on a scoring framework based on weighted averages or step ratings. Some rating programs provide a simple 'pass' or 'fail' evaluation, which reduces data complexity, but also over-simplifies the environmental issues to a large extent. For instance, the Environmental Ship Index simply indicates whether or not CO2-emissions from a vessel have been calculated, but does not require an assessment of the level of emissions. The rating schemes also differ in terms of the sources they rely upon: some are based on primary performance data reported by shipping companies, while others are based on vessel design 
specifications - which does not take into account differences in actual operational performance of ships. Some datasets are verified by third parties, typically ship classification societies, but mainly they are based on self-assessment by shipping companies.

Hybrid, quasi-private port authorities have also been active in this field. Differentiated port and fairway dues, based on ships' environmental footprints, are beginning to incentivize green initiatives among shipping companies. The World Ports Climate Initiative (WPCI), consisting of 42 ports world-wide, has established a benchmarking tool - the Environmental Ship Index (ESI), which 'identifies seagoing ships that perform better in reducing air emissions than required by the current emission standards of the International Maritime Organization' (World Ports Climate Initiative 2014). On this basis, the best performing vessels with the lowest emission levels are granted a reduction in port dues by some port authorities. While supportive of the concept, no companies interviewed mentioned this as a current driver of their current environmental mitigation measures. Reasons included: port and fairway dues constitute a very minor part of a ship's voyage costs (see also Stopford 2009); documentation requirements are demanding; and so far too few ports are covered.

Although faced with many challenges, private and multi-stakeholder efforts constitute an important emerging mechanism in the TEG of shipping. Cargo-owner demands for improvements in environmental performance from their carriers are emerging; and the rise of transnational green shipping rating schemes outside of (International Maritime Organization -led) international agreement formation processes are contributing to a hybrid governance landscape. International Maritime Organization orchestration of private, hybrid and public initiatives is thus critical in view of ensuring environmental progress. 


\section{Discussion}

In this section, we return more explicitly to our analytical framework to provide answers to the two research questions we posed in the introduction: (1) Why is shipping lagging behind other sectors in terms of its environmental protection standards; and (2) What potential has the International Maritime Organization to orchestrate better environmental protection standards and outcomes in shipping? Procedural delays in International Maritime Organization rule-making, stalled state ratification and implementation, strong industry pushback, as well as weak enforcement have all contributed to lagging improvements in shipping's environmental performance. Underlying this, unique structural features of the industry have shaped an institutional context that has dampened regulatory advances, including the 'flags of convenience' system (DeSombre 2006). Turning to our analytical framework, four dimensions also play an influencing role: issue visibility, interest alignment, issue scope and regulatory fragmentation and uncertainty.

Unique features of the shipping industry. Shipping is inherently multi-jurisdictional.

Contrary to onshore manufacturing plants, ships are mobile and ship registration, which defines a ship's nationality, is highly flexible. These factors shape industry practice and make shipping particularly 'footloose'. Seeking to lower their costs, many ship owners 'flag out'. Many open ship registers tend to attract ship-owners with promises of low regulatory burdens. Although a great diversity exists between open registers, these factors continue to challenge regulation for higher environmental protection standards (Cafruny 1987; DeSombre 2006; Hoffman and Kumar 2010). In 2013, an estimated 73 percent of the world fleet was registered under open registers, where owners' nationalities differed from the flags of the vessels (UNCTAD 2014). As the International 
Maritime Organization documents on their website, many open registers refrain from ratifying their conventions (IMO 2015a).

Issue visibility. Environmental issues in shipping generally have low public visibility and this has contributed to inaction. Firstly, with the exception of oil spills this is because the impacts generally have a delayed rather than an immediate effect. The historical reduction in oil spills from vessels represents a unique case of rising environmental standards that were driven jointly by policy makers and cargo-owners. Oil spills and the ensuing environmental damage are immediately visible to the general public (and concerns continue to mount), whereas the damage caused to marine ecosystems by invasive species and the negative human health effects of various emissions only gradually become evident. Moreover, the link between shipping and some of these problems - although clearly documented by research - may be less intuitive to the general public. Secondly, low visibility is a consequence of the business-to-business nature of shipping and its relative distance from consumers. Cargo carried on dry bulk ships, and to a large extent on tankers, undergoes several transformations in manufacturing plants before it reaches consumers.

Containerized cargo, on the other hand, is more directly visible to consumers, and as discussed, companies owning consumer brands have recently started to ask for information and tentatively place explicit environmental demands on container lines. The low visibility contributes to low public interest and in turn low political will form an obstacle to International Maritime Organization TEG orchestration.

Interest alignment. Shipping is a mature, highly competitive industry characterized by low cooperation between stakeholders which has hampered progress. Interests between government and industry with respect to environmental protection have traditionally diverged. For a long time, ship-owner associations worked explicitly to block or minimize international regulatory measures 
on the environmental footprint of shipping; they have also been lukewarm in relation to a number of private and hybrid initiatives that have emerged in recent years. However, this situation is shifting as cargo owners and a small segment of the shipping industry move towards a more proactive stance on environmental improvements. This may ease some of the constraints the International Maritime Organization faces in orchestrating TEG.

Issue scope. Environmental issues in shipping are wide ranging with inverse relationships in terms of their mitigation which makes regulatory alignment difficult. Current discussions on the environmental footprint of shipping cover a broad range of aspects, from human health and invasive species to global climate change. While some problems can be alleviated simultaneously, others are difficult to address together. For example, reduced fuel consumption will lower all types of emissions, but ballast water treatment and exhaust gas cleaning will increase energy consumption and $\mathrm{CO} 2$ emissions levels. In addition, the International Maritime Organization's conventions are claimed by ship-owners to be too broad and fragmented, and green rating schemes have had difficulties converting the diversity of issues into a coherent benchmark for environmental performance. The heterogeneous nature of these environmental problems clearly challenges both regulatory processes within the organization and its ability to orchestrate policy coherence.

Regulatory fragmentation and uncertainty. This factor has two components - a public regulatory component, and a private-hybrid governance component. Although the International Maritime Organization has the authority to provide global regulatory cohesion, the shipping regime is characterized by multi-level regulatory fragmentation and policy uncertainty that have distracted environmental progress and spurred the rise of transnational private environmental governance initiatives with their own associated challenges. In relation to the former, the 
International Maritime Organization has the capacity to provide a unified regulatory framework, but considerable uncertainty is related to crippled decision-making within the organization as meetings have become increasingly polarized. As the environmental protection agenda has been broadened, states have stalled in the ratification of International Maritime Organization conventions and in the implementation of national regulation. Ship-owners argue this uncertainty deters their investments in environmental protection. Moreover, considerable uncertainty relates to moving deadlines and weak enforcement of International Maritime Organization regulation. As regional rules develop to compensate, the regulatory unevenness across jurisdictions makes international ship operations more costly and complicated. Furthermore, enforcement of International Maritime Organization conventions resides with the contracting governments causing enforcement levels to vary. State controls at ports have played an essential role in helping to level the playing field through their right to detain or ban individual ships if deemed unseaworthy or non-compliant with ratified International Maritime Organization conventions (DeSombre 2006). However, it remains to be seen how port states will enforce the new SECA and BWMC regulations to raise environmental protection standards. Weak enforcement could penalize shipping companies, which invest in environmental upgrading.

As concerns private and hybrid governance mechanisms, we have shown that there has been a multiplication of rating schemes that have different foci and methodologies creating obstacles to progress. At this point in time, shipping companies and cargo-owners view the various rating methodologies as insufficient for effective benchmarking and for driving improvements. Nevertheless, some standardized reporting is emerging, such as with the CCWG CO2 accounting methodology for container shipping. Currently, 17 out of the top 20 container carriers participate in the CCWG, and new members are continuing to join. Data concerns are prevalent because 
benchmarking tools to a large extent rely on shipping company self-assessment. Only for tanker shipping safety do cargo-owners have a rigorous auditing scheme in place. Independent third party verification of the green ratings is therefore a likely future evolution. Classification societies, which have audited ships for three centuries, have yet to engage in the green shipping rating schemes but as we emphasize in the conclusion, they present an obvious opportunity as an independent auditor to verify and offer assurance of the performance data and ratings.

\section{<TABLE 2>}

Returning to the opening puzzle, the answer to why the global shipping sector has lagged in its environmental performance despite the long, well-established presence of the International Maritime Organization is several fold. It hinges not just on an understanding of the difficulties of the particular environmental issues and features of the shipping industry, but also on the dynamics of regulatory fragmentation, low issue visibility, poor (but possibly improving) interest alignment, and the broad, competing scope of issues involved. Each highlights the need for serious strategic reconsideration within the international organization, not only in general in relation to how it leads as a global regulation but also more specifically in terms of how to tackle these issues as an orchestrator of emerging private and hybridized governance mechanisms.

\section{Conclusion}

Maritime shipping binds global production and consumption and facilitates international trade. It plays a fundamental role in the growth of the world economy and is a major contributor to global environmental change through its local and cross-boundary air, water and land impacts. Addressing the environmental impacts of shipping is therefore an essential and pressing governance issue. In this article, we highlighted the complexities of transnational environmental 
governance in shipping, which includes a combination of international agreements, national and regional regulation, an increasing number of multi-stakeholder initiatives and benchmarking processes, and an early and tentative set of private demands from cargo-owners to improve selected environmental concerns. We explained why the shipping industry lags behind in environmental protection standards and why the International Maritime Organization's orchestration efforts have been minimal and fraught with difficulties. Even the prospect of further regulation (and the coming into place of actual agreements at the regional level on specific emissions) has not had the 'gorilla in the closet' effect in shipping that has been observed in other industries (Verbruggen 2013; Ponte and Daugbjerg 2015). The TEG landscape in shipping is increasingly fragmented, uncoordinated and fraught with difficulties. Industry uncertainties about regulatory compliance requirements and the lack of harmonization of voluntary green shipping standards are slowing the adoption of new business practices despite the increasing regulatory efforts. Both shipping and the specific environmental issues concerned are not particularly visible to the general public and consumers. While a narrow focus on $\mathrm{CO} 2$ emissions would be misplaced, tackling a broader range of issues makes orchestration more difficult. Industry and public interests are misaligned in relation to environmental concerns although, a partial realignment between parts of the shipping industry, national governments and 'green shipping' multistakeholder initiatives may be taking place in the EU and the US. All in all, environmental progress is lagging behind, with the 'green image' of shipping now questioned.

Given the transnational nature of shipping, its long history of self-regulation, and the challenges it faces, it is likely that private and hybrid governance of environmental issues will not lessen but rather establish a foothold. It is thus essential for the International Maritime Organization to accept the hybrid nature of the transnational environmental governance of 
shipping and address the challenges of its role as orchestrator within this expanded political arena. This includes direct as well as facilitative measures. As a priority, the International Maritime Organization will need to directly address the uncertainty and growing impatience concerning slipping regulatory deadlines, and redouble its efforts to fold the 'break-out' regional regulatory initiatives back under its global mantle.

Regarding green ship rating programs, at a minimum the International Maritime Organization needs to indirectly observe and track these private and hybrid initiatives to ensure they align as much as possible in their ultimate objectives. As a more directly approach, the organization should consider granting consultative status to the NGO-led green shipping initiatives, in order to enhance the standards' legitimacy and spur greater alignment of new initiatives. Currently, NGOs like Greenpeace and the WWF enjoy consultative status at the International Maritime Organization, but private governance bodies such as the CCWG, CSI and SSI do not.

Among numerous opportunities, the International Maritime Organization could also look to better understand and leverage the many lessons and experiences that the green rating programs have gathered over the last decade. These could serve as valuable inputs to discussions within new regulatory initiatives such as a global MRV-system. Specifically with respect to the global MRV development, the International Maritime Organization could consider aligning with existing green ship rating methodologies for calculation of environmental footprints. It could also promote and provide incentives to support these private initiatives to set-up independent audits of their green rating data sets to improve the quality of data available. Drawing on TEG theory, this could possibly be carried out successfully by an 'intermediary' such as the classification societies that have long histories of ship auditing. 
Ultimately, to improve global shipping performance, the International Maritime Organization will need to accept the sector's governance challenges and embrace its role as orchestrator: overseeing, leveraging and enabling private and hybrid efforts as a complement to national and international regulation - fundamentally spurring and guiding beyond-compliance green shipping innovation and environmental progress under the shadow of public authority.

\section{References}

Abbott, K.W., Snidal, D., 2009a. The governance triangle: Regulatory standards institutions and the shadow of the state. In W. Mattli and N. Woods, (eds.) The Politics of Global Regulation. Princeton: Princeton University Press, 44-88.

Abbott, K.W., Snidal, D., 2009b. Strengthening international regulation through transnational new governance: Overcoming the orchestration deficit. Vanderbilt Journal of Transnational Law, 42, 501-578.

Abbott, K.W., Snidal, D., 2010. International regulation without international government: Improving IO performance through orchestration. Review of International Organizations, 5, 315344.

Abbott, K.W., Snidal, D., 2013. Taking responsive regulation transnational: Strategies for international organizations. Regulation and Governance, 7, 95-113. 
Abbott, K.W., Genschel, P., Snidal, D., Zangl, B., 2015. Orchestration: Global governance through intermediaries. In Abbott, K.W., Genschel, P., Snidal, D., Zangl, B., eds. International Organizations as Orchestrators. Cambridge: Cambridge University Press.

Alter, K.J., Meunier, S., 2009. The politics of international regime complexity. Perspectives on Politics, 7, 13-24.

Anderson, K., Bows, A., 2012. Executing a Scharnow turn: Reconciling shipping emissions with international commitments on climate change. Carbon Management 3(6), 615-628.

Andonova, L.B., 2010. Public-private partnerships for the earth: Politics and the patterns of hybrid authority in the multilateral system. Global Environmental Politics, 10 (2), 25-53.

Andonova, L.B., Betsill, M., Bulkeley, H., 2009. Transnational climate governance. Global Environmental Politics, 9 (2), 52-73.

Asariotis, R., Benamara, H., 2012. Maritime transport and the climate change challenge. New York, NY: Earthscan.

Asariotis, R., Benamara, H., Hoffman, J.H., Jaimurzina, A., Premti, A., Rubiato, J.M., Valentino, V., Youssef, F., 2013. Review of Maritime Transport 2013. Geneva: United Nations Conference on Trade and Development. 
Auld, G., 2014. Confronting trade-offs and interactive effects in the choice of policy focus:

Specialized versus comprehensive private governance. Regulation and Governance, 8 (1), 126148.

Bäckstrand, K., 2008. Accountability of networked climate governance: The rise of transnational climate partnerships. Global Environmental Politics, 8 (3), 74-102.

Bax, N., Williamson, A., Aguero, M., Gonzalez, E. and Geeves, W., 2003. Marine invasive alien species: A threat to global biodiversity. Marine Policy, 27(4), 313-323.

Bazari, Z. Longva, T., 2011. Assessment of IMO mandated energy efficiency measures for international shipping. Estimated CO2 Emissions Reduction from Introduction of Mandatory Technical and Operational Energy Efficiency Measures for Ships, Project Final Report, 31.

Biermann, F., Pattberg, P., van Asselt, H., Zelli, F., 2009. The fragmentation of global governance architectures: A framework for analysis. Global Environmental Politics, 9 (4), 14-40.

Biermann, P., 2007. 'Earth system governance' as a crosscutting theme of global change research. Global Environmental Change 17, 326-337. 
BIMCO, 2014a. 'GHG and Market Based Measures (MBMs): BIMCO’s position’ Bagsvaerd, Denmark: BIMCO.

https://www.bimco.org/About/Viewpoint/04_Greenhouse_Gases_and\%20Market_Based_Measures.aspx, Accessed on 11 November 2014.

BIMCO, 2014b. 'Keep regulation global', Bagsvaerd, Denmark: BIMCO.

https://www.bimco.org/About/Viewpoint/01_Keep_Regulation_Global.aspx, Accessed 11 November 2014.

BIMCO, 2015. 'Viewpoint', Bagsvaerd, Denmark: BIMCO https://www.bimco.org/en/About/Viewpoint.aspx, Accessed 6 March 2015.

Briski, E., Ghabooli, S., Bailey, S.A., Macisaac, H.J., 2012. Invasion risk posed by macroinvertebrates transported in ships' ballast tanks. Biological Invasions, 14(9), 1843-1850.

Bows-Larkin, A., Anderson, K., Mander, S., Traut, M., Walsh, C., 2015. Nature Climate Change. 5, 293-295.

Buhaug, Ø., Corbett, J., Endresen, Ø, Eyring, V., Faber, J., Hanayama, S., Lee, D., Lee, D., Lindstad, H., Markowska, A., 2009. Second IMO GHG study 2009. London, UK: International Maritime Organization (IMO). 
Burgherr, P., 2007. In-depth analysis of accidental oil spills from tankers in the context of global spill trends from all sources. Journal of hazardous materials, 140, 245-256.

Cafruny, A.W., 1987. Ruling the Waves: The Political Economy of International Shipping. Berkeley: University of California Press.

Chan, F.T., Bailey, S.A., Wiley, C.J., Macisaac, H.J., 2013. Relative risk assessment for ballastmediated invasions at Canadian Arctic ports. Biological Invasions, 15(2), 295-308.

Corbett, J.J., Fischbeck, P., 1997. Emissions from Ships. Science, 278, 823-24, October 31.

Corbett, J.J., Winebrake, J.J., Green, E.H., Kasibhatla, P., Eyring, V., Lauer, A., 2007. Mortality from ship emissions: A global assessment. Environmental Science \& Technology, 41(24), 85128518.

Cullinane, K., Bergqvist, R., 2014. Emission control areas and their impact on maritime transport. Transportation Research Part D, 28D, 1-5.

Cutler, A. C., 1999. 'Private Authority in International Trade Relations: The Case of Maritime Transport', In A. C. Cutler, V. Haufler and T. Porter (eds), Private Authority and International Affairs. New York: State University of New York Press, 283-331. 
Dalsøren, S.B., Eide, M.S., Endresen, Ø., Mjelde, A., Gravir, G., Isaksen, I.S.A., 2009. Update on emissions and environmental impacts from the international fleet of ships: The contribution from major ship types and ports. Atmospheric Chemistry and Physics, 9, 2171-2194.

Danish Shipowners' Association, 2012. Green transport of global trade - The Danish shipping industry's initiatives and positions on climate and environmental issues. Copenhagen: Danish Shipowners' Association.

https://www.shipowners.dk/download/Publications_Model_Publication/5/green-transport-ofglobal-trade.pdf.

Danish Shipowners’ Association, 2014. Policy Paper on Climate. Copenhagen: Danish Shipowners' Association. https://www.shipowners.dk/en/aktuelle-udfordringer/miljoe-ogklima/klima/.

Danish Shipowners' Association, 2015. 'Danish Shipping in a Global Leading Position', https://www.shipowners.dk/en/dansk-skibsfart-i-tal-p2/dansk-skibsfart/. Danish Shipowners' Association, Accessed 4 March 2015.

Dauvergne, P., Lister, J., 2012. Big brand sustainability: Governance prospects and environmental limits, Global Environmental Change, 22(1) 36-45.

DeSombre, E.R., 2006. Flagging Standards: Globalization and Environmental, Safety, and Labor Regulations at Sea. Cambridge, MA: The MIT Press. 
Derkx, B., Glasbergen, P. 2014. Elaborating global private meta-governance: An inventory in the realm of voluntary sustainability standards. Global Environmental Change, 27: 41-50.

Dibacco, C., Humphrey, D.B., Nasmith, L.E., Levings, C.D., 2012. Ballast water transport of nonindigenous zooplankton to Canadian ports. ICES Journal of Marine Science: Journal du Conseil 69 (3), $483-491$.

DieselNet 2015. Emissions standards, https://www.dieselnet.com/. Accessed 27 February 2015.

Dingwerth, K., Pattberg, P., 2009. World politics and organizational fields: The case of transnational sustainability governance. European Journal of International Relations, 15 (4), 707 744.

ECSA, 2009. ‘Annual report 2008-2009', Brussels: European Community Shipowners' Associations.

European Commission, 2013. Time for international action on CO2 emissions from shipping, Brussels: European Commission.

European Commission, 2015a. 'Reducing emissions from the shipping sector' http://ec.europa.eu/clima/policies/transport/shipping/index_en.htm, Brussels, Belgium: European Commission, Accessed 4 February 2015. 
European Commission, 2015b.’Pollution from road vehicles', Brussels, Belgium: European Commission, http://ec.europa.eu/environment/air/transport/road.htm. Accessed 3 March 2015.

Foley, P., 2012. The political economy of marine stewardship council certification: Processors and access in Newfoundland and Labrador's inshore shrimp industry. Journal of Agrarian Change, 12 $(2-3), 436-45$.

Fransen, L., 2012. Multi-stakeholder governance and voluntary programme interactions: Legitimation politics in the institutional design of Corporate Social Responsibility. SocioEconomic Review, 10 (1), 163-192.

Gale, F., Haward, M., 2011. Global Commodity Governance: State Responses to Sustainable Forest and Fisheries Certification. Basingstoke and New York: Palgrave.

Gold, E., 1981. Maritime Transport: The Evolution of International Marine Policy and Shipping Law. Lexington, MA: Lexington Books.

Green, J.F., 2013. Order out of chaos: Public and private rules for managing carbon. Global Environmental Politics, 13 (2), 1-25.

Green, J.F. 2014. Rethinking Private Authority: Agents and entrepreneurs in global environmental governance. Princeton: Princeton University Press. 
Graham, E.R., Thompson, A., 2015. 'Efficient orchestration? The Global Environmental Facility in the governance of climate adaptation' in K.W. Abbott, P. Genschel, D. Snidal, B. Zangl (eds) International Organizations as Orchestrators. Cambridge: CUP.

Guldbrandsen, L.H., 2014. Dynamics governance interactions: evolutionary effects of state responses to non-state certification programs. Regulation and Governance, 8 (1), 74-92.

Haas, P., 2004. Addressing the global governance deficit. Global Environmental Politics, 4(4), 121.

Hackmann, B., 2012. Analysis of the governance architecture to regulate GHG emissions from international shipping. International Environmental Agreements, 12, 85-103.

Hale, T., Roger, C., 2014. Orchestration and transnational climate governance. Review of International Organizations, 9, 59-82.

Hiremath, A.M., Tilwanker, A.K., Asolekar, S.R., 2015. Significant steps in ship recycling vis-àvis wastes generated in a cluster of yards in a cluster of yards in Alang: A case study. Journal of Cleaner Production, 87, 520-532.

Hoffmann, M.J., 2011. Climate Governance at the Crossroads. Oxford: Oxford University Press. 
Hoffmann, J., Kumar, S., 2010. 'Globalisation: the maritime nexus' in Grammenos, C. (ed.), The Handbook of Maritime Economics, second edition, London: Lloyd's List, 35-64

Huijer, K., 2005. Trends in oil spills from tanker ships 1995-2004. International Tanker Owners Pollution Federation (ITOPF), London, 30.

ICS, 2015. 'Environmental protection', http://www.ics-shipping.org/key-issues/all-key-issues-(full-list), London: International Chamber of Shipping. Accessed 16 February 2015.

IMO, 2013. A concept of a sustainable maritime transportation system, World Maritime Day, September 2013, London: International Maritime Organization [online].

IMO, 2014. 'About IMO’ http://www.imo.org/Pages/home.aspx, London: IMO. Accessed 11 November 2014.

IMO 2015a. Status of Conventions, http://www.imo.org/About/Conventions/StatusOfConventions/Pages/Default.aspx London: IMO. Accessed 3 March 2015.

IMO 2015b. Market-based measures, http://www.imo.org/OurWork/Environment/PollutionPrevention/AirPollution/Pages/Market-BasedMeasures.aspx, London: IMO. Accessed 3 March 32015. 
IMO 2015c. Recycling of Ships, (http://www.imo.org/en/OurWork/Environment/ShipRecycling/Pages/Default.aspx). London, IMO. Accessed 22 June 2015.

IPCC, 2015. 'History of the IPPC', https://www.ippc.int/en/history-of-the-ippc/, Rome: IPCC Secretariat. Accessed 4 March 2015.

Johnson, H., Johansson, M., Andersson, K., Södahl, B., 2013. Will the ship energy efficiency management plan reduce $\mathrm{CO} 2$ emissions? A comparison with ISO 50001 and the ISM code. Maritime Policy \& Management 40, 177-190.

Karim, M.S., 2015. Prevention of Pollution of the Marine Environment from Vessels: The Potential and Limits of the International Maritime Organization. London: Springer.

Keohane, R.O., Victor, D.G., 2011. The regime complex of climate change. Perspectives on Politics, 9, 7-21.

Lister, J. 2011. Corporate Social Responsibility and the State. Vancouver: UBC Press.

Lister, J. 2015. Green shipping: Governing sustainable maritime transport. Global Policy. 6(2) 118-129. 
Litehauz and Lack, D.A., Thuesen, J. Elliot, R., and ERRIA. 2012. Investigation of appropriate control mechanisms (abatement technologies) to reduce black carbon emissions from International shipping. Study report prepared for the IMO, November 20, 2012.

Lloyd's List, 2010. 'EU owners call for sulphur limit reversal', Lloyd's List, March 25 .

Lloyd's List, 2011a. 'EU calls for urgent climate change action', Lloyd's List, June 29.

Lloyd's List, 2011b. 'ICS presses European Commission to keep shipping out of emissions trading', Lloyd's List, August 8.

Lloyd's List, 2011c. 'Drowned out by the screaming greens', Lloyd's List, November 4.

Lloyd's List, 2012. 'Shipping refuses to play cash cow in the war against climate change', Lloyd's List, 26 November.

Lloyd's List, 2014a. 'Compromise found over new dates for NOx emission clampdown', Lloyd's List, April 4.

Lloyd's List, 2014b. 'Danes push for more complex European CO2 reporting scheme', Lloyd's List, October 7. 
Lloyd's List, 2015a. 'Industry viewpoint: the six challenges facing the next head of the IMO', Lloyd's List, February 3.

Lloyd's List, 2015b. 'Rules on environment and employment could disrupt European maritime cluster", Lloyd's List, March 3.

Mathers, J., 2012. Smart moves. Environmental Defense Fund, New York. [online].

McGonigle, R.M., Zacher, M., 1979. Pollution, Politics and International Law: Tankers at Sea. Berkeley: University of California Press.

Merrie, A., Dunn, D.C., Metian, M., Boustany, A.M., Takei, Y. Elferink, A.O. Ota, Y., Christensen, V., Halpin, P.N., Österblom, H. 2014. An ocean of surprises - Trends in human use, unexpected dynamics and governance challenges in areas beyond national jurisdiction. Global Environmental Change 27: 19-31.

Mehta, S.V., Haight, R.G., Frances, F.R., Polasky, S., Robert C. Venette, R.C., 2007. Optimal detection and control strategies for invasive species management. Ecological Economics 61, 237245.

Mitchell, R., 1994. Intentional Oil Pollution at Sea. Cambridge, MA: The MIT Press.

Mol, A.P.J., 2010. Environmental authorities and biofuel controversies. Environmental Politics, 19 (1), 61-79. 
Molenaar, E.G., 2009. Arctic marine shipping: Overview of the international legal framework, gaps and options. Journal of Transnational Law and Policy 18(2), 290-325.

Molnar, J.L., Gamboa, R.L., Revenga, C., Spalding, M.D., 2008. Assessing the global threat of invasive species to marine biodiversity. Frontiers in Ecology and the Environment, 6(9), 485-492.

Mukherjee, P.K., Brownrigg, M., 2013. Farthing on International Shipping. Berlin and Heidelberg: Springer.

Nikopoulou, Z., Cullinane, K., Jensen, A., 2013. The role of cap-and-trade market in reducing NOx and SOx emissions: Prospects and benefits for ships within the Northern European ECA. Proc. IMechE Part M. J. Engineering for the Maritime Environment, 227(2), DOI: $10.1177 / 1475090212459130$.

Norwegian Shipowners' Association, 2014. Blue Seas - Green Future, Environmental strategy for the Norwegian Shipowners' Association, Oslo: Norwegian Shipowners' Association.

Oberthür, S., Ott, H.E., 1999. The Kyoto Protocol: international climate policy for the 21 st century. Heidelberg: Springer.

Overdevest, C., Zeitlin, J., 2014. Assembling an experimentalist regime: Transnational governance interactions in the forest sector. Regulation and Governance, 8 (1), 22-48. 
Paulsen, G., Andersen, H.W., Collett, J.P., Stensrud, I.T., 2014. Building Trust. The history of DNV 1864-2014. Lysaker: Dinamo Forlag.

Ponte, S., Daugbjerg, C., 2015. Biofuel sustainability and the formation of transnational hybrid governance. Environmental Politics, 24(1), 96-114.

Psaraftis, H. N., 2012. Market-based measures for greenhouse gas emissions from ships: A review source. WMU Journal of Maritime Affairs 11(2), 211-232.

Roe, M., 2012. Maritime Governance and Policy-Making. London: Springer.

Sabel, C.F., Zeitlin, J., 2008. Learning from difference: The new architecture of experimentalist governance in the EU. European Law Journal, 14, 271-327.

Sala, O.E., Chapin III, F.S., Armesto, J.J., Berlow, E., Bloomfield, J., Dirzo, R., Huber-Sanwald, E., Huenneke, L.F., Jackson, R.B., Rik Leemans, A.K., Lodge, D.M., Mooney, H.A.,'n Oesterheld, M., LeRoy Poff, N., Sykes, M.T., Walker, B.H., Walker, M., Wall, D.H., 2000. Global Biodiversity Scenarios for the Year 2100. Science 287, 1770-74.

Schleifer, P., 2013. Orchestrating sustainability: The case of European Union biofuel governance. Regulation and Governance, 7 (4), 533-546. 
Schmalensee, R., Joskow, P.L., Ellerman, A.D., Montero, J.B., Bailey, E.M., 1998. An Interim Evaluation of Sulfur Dioxide Emissions Trading. Journal of Economic Perspectives, 12(3), 53-68.

Smith, T.W.P., Jalkanen, J.P., Anderson, B.A., Corbett, J.J., Faber, J., Hanayama, S., O'Keeffe, E., Parker, S., Johansson, L., Aldous, L., Raucci, C., Traut, M., Ettinger, S., Nelissen, D., Lee, D.S., Ng, S., Agrawal, A., Winebrake, J.J., Hoen, M., Chesworth, S., Pandey, A., 2014. Third IMO GHG Study 2014. International Maritime Organization (IMO), London, UK.

Stopford, M., 2009. Maritime Economics, $3^{\text {rd }}$ Edition. London: Routledge.

Strange, S., 1976. Who Runs World Shipping? International Affairs, 52(3), 346-367.

Sustainable Shipping Initiative (SSI), 2014. The Sustainable Shipping Initiative [Homepage of Sustainable Shipping Initiative], [Online]. Available: http://ssi2040.org/ Accessed 17 July 2014. Tan, A.K., 2006. Vessel-source Marine Pollution: The Law and Politics of International Regulation. Cambridge: Cambridge University Press.

UK Chamber of Shipping, 2012. The Chamber of Shipping Annual Review 2011-12, London: UK Chamber of Shipping.

UNCTAD, 2014. Review of maritime transport 2014. Geneva: United Nations Conference on Trade and Development Publication. 
USCG, 2014. 'US Coast Guard Ballast Water Management Program', https://homeport.uscg.mil/mycg/portal/ep/browse.do?channelId=18366\&channelPage=\%2Fep\%2Fchannel\%2Fdefault.jsp\&pageTypeId=13489\&BV_SessionID=@@@@@1 611264088.1414928151@@@@\&V EngineID=ccccadgehkkekghcfngcfkmdfhfdfgl.0, US Coast Guard, Accessed 11 November 2014.

Van Aardenne, J., Colette, A., Degraeuwe, B., Hammingh, P., De Vlieger, I., 2013. The impact of international shipping on European air quality and climate forcing. Copenhagen: European Environment Agency, http://dx.doi.org/10.2800/75763.

Van Leeuwen, J., 2010. Who Greens the Waves? Changing Authority in the Environmental Governance of Shipping and Offshore Oil and Gas Production. The Netherlands: Wageningen Publishers.

Verbruggen, P., 2013. Gorillas in the closet? Public and private actors in the enforcement of transnational private regulation. Regulation and Governance, 7 (4), 512-532.

Viana, M., Hammingh, P., Colette, A., Querol, X., Degraeuwe, B., de Vlieger, I., van Aardenne, J., 2014. Impact of maritime transport emissions on coastal air quality in Europe. Atmospheric Environment, 90, 96-105.

World Ports Climate Initiative, 2014. Environmental Ship Index ESI [Homepage of World Ports Climate Initiative], [Online]. Available: http://esi.wpci.nl/Public/Home Accessed 17 July, 2014. 
Zacher, M.W., Sutton, B.A., 1996. 'The International Shipping Regime', In M.W. Zacher and B.A. Sutton (Eds.), Governing Global Networks: International Regimes for Transportation and Communications. Cambridge: Cambridge University Press, 36 -80.

Young, O. R., 2009. The Arctic in play: Governance in a time of rapid change. The International Journal of Marine and Coastal Law, 24, 423-442.

Zelli, F., van Asselt, H., 2013. The institutional fragmentation of global environmental governance: Causes, consequences, and responses. Global Environmental Politics, 13 (3), 1-13. 